Fresh start for Europe

SIR - The article by I. Barry Holland, "A fresh start for European science" (Nature 367, 592; 1994) prompts me to say that the European Environmental Research Organisation (EERO) already has a policy of sponsoring individuals rather than projects and has been doing so since it began in 1990. The output so far suggests that a focus on individuals is indeed cost-effective, and, compared with funding programmes and projects, is also less cumbersome.

Organizations such as the EERO aim to build on scientific opportunities likely eventually to produce useful results; they function best by funding the research leaders who identify these opportunities. The European Commission policy presumably responds essentially to political and socio-economic concerns and so can appropriately lead to the funding of customer-driven research programmes. Room should exist for both kinds of structure.

I read with interest Holland's comments about rationalizing $\mathrm{PhD}$ training and career development. A first step towards influencing education and training of graduates and undergraduates can be through involving in training courses the university staff responsible for teaching at those levels. The EERO already has a programme of such training courses in the environmental sciences. If one tries to develop guidelines as Holland suggests, they must somehow be compatible with the complex and heterogeneous course structures and curricula that exist across the continent of Europe. I am sure this must be feasible, but it will take time.

John V. Lake

European Environmental

Research Organisation,

POBox 191, NL-6700 AD Wageningen,

The Netherlands

\section{Nuclear weapons}

SIR - In Laurence Martin's review (Nature 367, 603-604; 1994) of the Pugwash book $A$ Nuclear-Weapon-Free World: Desirable? Feasible? he notes the argument that the retention of nuclear weapons by some states is an assurance against their use on themselves. This does not sufficiently take into account the great unlikelihood that nations not now possessing nuclear weapons would forgo indefinitely the presumed advantages of having them.

The Non-Proliferation Treaty (NPT) will be considered for renewal in 1995, and dissatisfaction with the discriminatory nature of 'have' and 'have-not' nations has been great among the 'have-nots'. In fact, this was why the NPT conference in 1990 could not agree on a final statement. The 1995 conference is thus in jeopardy, and we may face a breakdown in whatever restraint the NPT now exerts on 'havenot' countries that may be unwilling to continue their lessened political clout in comparison with the 'have' countries.

There is, of course, the unprovable assumption that the threatening postures of the United States and the former Soviet Union during the Cold War served to keep the world free of nuclear war. Clearly, the restraint and caution of the leaders of those countries played an important role. If some countries continue to assert their exclusive right to possess such weapons, however, the NPT will be at continuous risk. It is virtually certain that over time some 'have not' countries will not forgo the political and military status that the 'have' countries now possess. With the spread of such weapons to additional countries, and given the political instabilities which will surely continue, it would be foolhardy to depend on continued restraint by leaders in crises in an increased number of nuclear-weapon powers. This possibility plus the examples of Iraq, Libya, Iran and some African countries, apart from the non-declared possessors of nuclear weapons, should give pause to those who still support the possession of such arms; but apparently they remain impervious to the logical conclusion that should be drawn.

As the Pugwash book cogently argues, a nuclear-weapon-free world will be a difficult and long-term undertaking, but there is no alternative if we are to minimize the everlasting threat such weapons pose.

\section{Martin M. Kaplan}

23Chemin de Marly,

1245 Collonge, Switzerland

\section{Don't eat it}

SIR - The debate on the use of bovine somatotropin (BST) to increase milk yield in dairy cows is not helped by misinformation on its apparent use in agricultural practice (Nature 367, 582; 1994). BST licensed for use in the United States is administered in a slow-release form by intramuscular injection not "by adding BST to feed". Feeding peptide hormones to cows would be an expensive form of protein supplementation in the diet with no effect on milk output; similar protein digestion would of course occur in humans consuming milk products containing the natural hormone.

\section{Chris Seal}

\section{David Parker}

\section{Department of Biological}

and Nutritional Sciences,

University of Newcastle,

Newcastle upon Tyne NE1 7RU, UK
How to hasten peace in Ireland

SIR - Recently, John Maddox briefly reviewed the origins and status of universities in Northern Ireland and the Irish Republic (Nature 368, 13; 1994).

I am an Englishman who spent 30 years at the Queen's University of Belfast and I believe that Maddox has committed the same error as many other Englishmen, especially politicians. Although the prospects for achieving a peaceful settlement in Northern Ireland appear unpromising in the short term, there is one guaranteed method of achieving agreement between the different factions of the population. Proposals for their future emanating from Englishmen who have never lived in Northern Ireland will evoke a united opposition.

Maddox suggests integration of the Irish universities. I believe that his wellmeaning suggestion would fail for the reason I have given. He will be interested to learn, however, that biochemists from both parts of Ireland decided to form a group for intellectual exchange in 1966. The Biochemical Society gave its blessing to the scheme and the Irish Area Section of the society was formed. The society has funded an annual meeting, including a novel scheme for predoctoral students, at the various institutions. In addition, the National Committee for Biochemistry in the Republic has routinely had a repre. sentative from the Queen's University since then.

I know that other academic disciplines have been involved in similar academic collaborative exercises. These successes have resulted from the efforts of academics and students and not from the activities of politicians of either country.

My message then is not to force-feed the populace of either part of Ireland with a political diet that will evoke opposition rather than achieve the hoped-for peaceful settlement. Westminster and Dublin should devote less attention to sowing seeds of peace of their choosing and more to fostering any attractive seedlings that emerge from the grass roots. This is not a proposal for British disengagement but a plea for patience. In my view, it will take at least a generation for the population of Northern Ireland to recover from the trauma of the past 25 years. Altering the funding arrangements of universities, especially if that implies further academic economies, will do nothing to hasten the process.

\section{D.T. Elmore}

Eslaforde,

40 Clover Place,

Eynsham,

Witney,

Oxfordshire OX81QL, UK 